\title{
Physiological quality of coffee seeds produced under different levels of solar radiation and maturation stages ${ }^{1}$
}

\author{
Danielle Pereira Baliza ${ }^{2 *}$, Franciele Caixeta ${ }^{3}$, Édila Vilela de Resende Von Pinho ${ }^{3}$, \\ Rodrigo Luz da Cunha ${ }^{4}$, Denize Carvalho Martins ${ }^{3}$, \\ Sttela Dellyzete Veiga Franco da Rosa ${ }^{5}$
}

\begin{abstract}
In Brazil, although the coffee plantations are predominantly grown under full sunlight, the use of agroforestry systems can lead to socioeconomic advantages, thus providing a favorable environment to the crop by promoting its sustainability as well as environmental preservation. However, there is a lack of information on physiological quality of the coffee seeds produced under different levels of solar radiation. Within this context, the objective of this study was to evaluate the influence of different levels of solar radiation and maturation stages on the physiological quality of coffee (Coffea arabica L.) seeds, cv. Acaiá Cerrado MG-1474. Three levels of solar radiation (plants grown under full sunlight; under plastic screens of 35\% shading; and under plastic screens of 50\% shading) and three maturation stages (cherry, greenish-yellow and green) were assessed. Physiological quality of seeds was assessed by using germination test, first count of germination, abnormal seedlings, dead seeds, and seedlings with open cotyledonary leaves. Electrophoretic analysis of isoenzymes catalase, esterase, superoxide dismutase and peroxidase was also performed. With the evolution of development the coffee seeds presents increases on physiological quality, and at its beginning the seeds show improvements on quality with the reduction of solar radiation.
\end{abstract}

Index terms: Coffea arabica, germination, vigor, isoenzymes.

\section{Qualidade fisiológica de sementes de café produzidas sob diferentes níveis de radiação solar e estádios de maturação}

\begin{abstract}
RESUMO - No Brasil, embora haja predomínio do cultivo do cafeeiro a pleno sol, o uso de sistemas agroflorestais pode induzir vantagens sócioeconômicas apresentando um ambiente favorável para a cultura, promovendo sustentabilidade e preservação do ambiente. No entanto, faltam informações sobre a qualidade fisiológica das sementes de café produzidas sob diferentes níveis de radiação solar. Neste contexto, o objetivo deste trabalho foi avaliar a influência de diferentes níveis de radiação solar e estádios de maturação, na qualidade fisiológica de sementes de café (Coffea arabica L.), cultivar Acaiá Cerrado MG-1474. Foram utilizados três níveis de radiação solar (plantas a pleno sol e sob sombrites de $35 \%$ e de $50 \%$ de sombra) e três estádios de maturação (cereja, verde-cana e verde). A qualidade fisiológica das sementes foi avaliada por meio do teste de germinação, primeira contagem, plântulas anormais, sementes mortas e plântulas com folhas cotiledonares abertas. Foi realizada ainda a análise eletroforética das isoenzimas catalase, esterase, superóxido dismutase e peroxidase. As sementes de café apresentam aumento da qualidade fisiológica com a evolução do seu desenvolvimento e, no início do seu desenvolvimento, apresentam melhoria da qualidade com a redução da radiação solar.
\end{abstract}

Termos para indexação: Coffea arabica, germinação, vigor, isoenzima.

${ }^{1}$ Submitted on $08 / 31 / 2011$. Accepted for publication on 01/10/2012.

${ }^{2}$ Departamento de Agricultura e Ambiente, Instituto Federal de Educação, Ciência e Tecnologia do Sudeste de Minas Gerais, 36180-000-Rio Pomba, MG, Brasil.

${ }^{3}$ Departamento de Agricultura, Universidade Federal de Lavras, Caixa Postal 3037, 37200-000-Lavras, MG, Brasil.
${ }^{4}$ Empresa de Pesquisa Agropecuária de Minas Gerais/Sul de Minas, Caixa Postal 176, 37200-000-Lavras, MG, Brasil.

${ }^{5}$ Empresa Brasileira de Pesquisa Agropecuária, Departamento de Agricultura, Caixa Postal 37, 37200-000-Lavras, MG, Brasil.

*Corresponding author $<$ danibaliza@yahoo.com.br> 


\section{Introduction}

The species Coffea arabica L. (Rubiaceae) is native from Ethiopia, where it permanently grows under protection of shading trees. Its adaptation to shaded conditions favors its cultivation in agroforestry systems, a practice widely used in the majority of Latin-American producing countries (DaMatta, 2004; Morais et al., 2004). In Brazil, with wider and more suitable areas for coffee cultivation, the cultivars were genetically improved for high productivity under full sunlight (DaMatta, 2004; Kanten and Vaast, 2006; Gomes et al., 2008). Although in Brazil coffee cultivation is done under full sunlight, the use of agroforestry systems can lead to socioeconomic advantages mainly for the small and median rural producers. Several factors may be cited as examples of these advantages: significant reductions on production costs; exploitation of other commercial products (fruits, crude latex, hardwood, and firewood, among others) within the same cultivation area; independence of external nutrient inputs, due to higher recycling of nutrients from decomposing of leaves and branches from trees; besides allowing that the coffee beans produced are of differentiated quality, thus widening new market and price options (DaMatta, 2004).

When installed at the proper time, i.e., at beginning of rainy season, the coffee plantation can have its development anticipated, besides having its percentage of replanting reduced, since the period in which the new seedling remains under favorable climatic conditions will be longer. The coffee seeds, however, present slow germination, increasing considerably the seedling growth period in addition to lowering its longevity (Guimarães et al., 2002; Pereira et al., 2002; Rosa et al., 2006; Macedo and Lopes, 2008; Sofiatti et al., 2008), conditions that prevent coffee seedling full formation within suitable period and under favorable climatic conditions for establishment of new coffee plantations.

There is not available information, however, on the influence of solar radiation levels on physiological quality of coffee seeds. It is known that shaded coffee plants produce beans of higher quality, once the shading favors a more adequate filling and a slow ripening for the beans, besides providing changes on chemical composition of these beans (Vaast et al., 2006).

For production of coffee commercial seeds, the harvest at maturation cherry stage is recommended (Mendes et al., 2002). Coffee seeds, however, normally reach their maximum germination capacity when the fruits are at the greenish-yellow or cherry stages; and it has been suggested that fully mature seeds of species sensitive to desiccation may not present maximum vigor due to a probable initiation of the germination process at the end of maturation.

According to Marcos-Filho(2005) the seed deterioration is a process induced by a series of physiological, biochemical, physical, and cytological changes, which initiates starting from the physiological maturation and occur in a progressive manner leading to reduction of their quality. The main changes related to the deterioration process are degradation and inactivation of enzymes (Copeland and McDonald, 2001). In their majority, the isoenzymes are responsible for the anti-oxidation and remotion actions of free radicals. The enzymatic systems, processors of free radicals, include superoxide dismutase, which catalyses the change of the superoxide $\left(\mathrm{O}_{2}^{-}\right)$into $\mathrm{H}_{2} \mathrm{O}_{2}$ and $\mathrm{O}_{2}$ and the enzymes involved on the deoxidization of $\mathrm{H}_{2} \mathrm{O}_{2}$, such as catalase, glutathione reductase, and ascorbate, among other peroxidases (Guimarães et al., 2002). The activity of these enzymes, which are known as removers of free radicals, or "scavengers" enzymes, is frequently associated to degree of tolerance to desiccation and seed deterioration.

In a study of tolerance to desiccation in seeds of Coffea arabica, harvested at different developmental stages, Brandão-Júnior et al. (2002a) have found that the enzymes catalase and peroxidase have had their activity increased when the seeds were dried. The authors have concluded that these enzymes are probably involved in the mechanism of tolerance to desiccation in seeds of this species. In another study, Brandão-Júnior et al. (2002b) have found that a higher activity of the scavengers enzymes generally occurs in seeds harvested at the cherry stage followed by stages greenish-yellow and green, suggesting that enzymatic activity is linked to development stages of coffee seeds.

In face of interest in determining the correlation between physiological maturity and shading on physiological quality of coffee seeds, the objective of this research work was to verify the influence of different levels of solar radiation and maturation stages on physiological quality of coffee seeds.

\section{Material and Methods}

The experiment was carried out in the Coffee Cropping Sector and Central Laboratory of Seeds, Federal University of Lavras, State of Minas Gerais, Southeastern Brazil, using coffee plants of the Arabica species, cv. Acaiá Cerrado MG-1474, planted in 1998 with plant spacing within row of $0.5 \mathrm{~m} \times 3.5 \mathrm{~m}$ between the rows. In 2007, 
the coffee plantation went through drastic pruning, in a low level of the trunk, for canopy renovation. In 2009, the coffee plants were subjected to three different levels of solar radiation (full sunlight, shading through 35\% and $50 \%$ shading screens). The plots were composed of eight plants in full production. After 14 months of installation of the new system of coffee plantation conduction, the fruits were harvested; the seeds were extracted and manually freed from the external mucilage; and were then dried at room temperature until reaching 13\% moisture content. For assessment of physiological quality, seeds were subjected to the following tests:

Germination: four subsamples of 50 seeds each (with manual removal of parchment) per plot were used for this test. The seeds of each subsample were then evenly arranged on top of two sheets of paper towels, covered with another sheet of the same paper, moistened with sterile distilled water, in a proportion equivalent to 2.5 times the mass of dry substrate, made into rolls and subsequently placed into a seed germinator at temperatures from $20^{\circ} \mathrm{C}$ to $30^{\circ} \mathrm{C}$. The counting was performed 30 days after test installation, according to Rules for Seed Analysis (Brasil, 2009), considering normal the apparently healthy seedlings with radicle and hypocotyl larger than $2 \mathrm{~cm}$. Results were expressed in percentage.

First count of germination: was determined jointly with the germination test and has consisted in the counting of the normal seedlings at the $15^{\text {th }}$ day after test beginning. Results were expressed in percentage of normal seedlings, which was computed by using the mean of the four results obtained for subsamples.

Abnormal seedlings: was determined jointly with the germination test and has consisted in the counting of abnormal seedlings that have not presented the pattern previously described; performed 30 days after test beginning. Results were expressed in percentage of abnormal seedling.

Dead seeds: determined jointly with the germination tests, this test has consisted in the counting of the dead seeds, which was carried out 30 days after beginning the test and had results expressed in percentage. According to Rules for Seed Analysis (Brasil, 2009) were considered dead seeds those whose: germination did not occur; were not either hard or dormant; were generally flabby and/or infected with microorganisms; and have not presented any signal of germination.

Seedlings with opened cotyledonary leaves: determined jointly with the germination test, it has consisted in the counting of seedlings that have had fully opened their cotyledonary leaves 45 days after test beginning. For this assessment, only two maturation stages (cherry and greenish-yellow) were considered and results were expressed in percentage.

Electrophoretic analysis of isoenzymes: these analyses were performed for the enzymes catalase (CAT), esterase (EST), superoxide dismutase (SOD), and peroxidase (PO). Electrophoresis were performed using polyacrylamide gels ( $7 \%$ separator gel; $4.5 \%$ concentrator gel), with Tris-glycin gel/electrode buffer system, $\mathrm{pH}$ 8.9. Entire seeds, which were then macerated, were used for extraction of isoenzymes. For the quantity of $100 \mathrm{mg}$ of seed dust were added $250 \mathrm{~mL}$ of 0.2 M Tri-HCL extraction buffer ( $0.2 \%$ B-mercaptoethanol; $0.4 \%$ PEG; $1 \mathrm{mM}$ EDTA), except for the peroxidase enzyme that was extracted in potassium phosphate buffer $(0.1 \mathrm{M}$; $\mathrm{pH} 7.8$; $0.2 \%$ ß-mercaptoethanol). The homogenized was incubated in ice for $1 \mathrm{~h}$ and centrifuged at $16,000 \mathrm{rpm}$, at $4{ }^{\circ} \mathrm{C}$, for 60 min. and immediately after, $40 \mu \mathrm{L}$ of the supernatant was deposited in each groove of the gel. Staining procedures for the enzymatic systems already cited were performed according to methodology described by Alfenas et al. (1991).

A randomized block experimental design, with the treatments arranged in a $3 \times 3$ factorial scheme [three levels of solar radiation (full sunlight, and shading with $35 \%$ and $50 \%$ shading screens) $x$ three stages of maturation (green, greenish-yellow, and cherry)] was used. ANOVA of data was performed and the Tukey test was applied to compare means, at $5 \%$ probability, using the "SISVAR" computational program (Ferreira, 2003).

\section{Results and Discussion}

Through results of ANOVA it was possible to verify that have occurred significant interaction between solar radiation levels and maturation stages in the variables: radicle protrusion; normal seedlings; and dead seeds. Results for abnormal growth of seedlings and for seedlings with open cotyledonary leaves at 45 days, however, showed significant effects only for seed maturation stages (Tables 1, 2, 3, 4 and 5).

Data shown on Table 1 allow verifying that the cherry maturation stage has provided coffee seeds with the best quality, independently of solar radiation conditions. Seeds harvested at the greenish-yellow maturation stage besides presenting intermediary vigor between those seeds harvested at green and cherry stages have also not suffered influence of solar radiation (Table 1). These results are similar to those found by Veiga et al. (2007) and Rosa 
et al. (2011) who in studies with coffee seeds, have also verified higher values for germination and vigor of seeds harvested at the cherry stage than the values observed for seeds harvested at the greenish-yellow stage. Guimarães et al. (2002) have also found that vigor of coffee seeds perceptibly increases between the green and greenishyellow maturation stages, as detected in this study.

Table 1. Percentage of radicle protrusion of coffee seeds produced in three different levels of solar radiation and harvested in three different stages of maturation.

\begin{tabular}{cccc}
\hline \multirow{2}{*}{$\begin{array}{c}\text { Level of solar } \\
\text { radiation }\end{array}$} & Cherry & $\begin{array}{c}\text { Greenish- } \\
\text { yellow }\end{array}$ & Green \\
\cline { 2 - 4 } & $96 \mathrm{aA}^{(1)}$ & $76 \mathrm{aB}$ & $26 \mathrm{bC}$ \\
Full sunlight & $98 \mathrm{aA}$ & $81 \mathrm{aB}$ & $50 \mathrm{aC}$ \\
$35 \%$ shading & $96 \mathrm{aA}$ & $69 \mathrm{aB}$ & $45 \mathrm{aC}$ \\
\hline $50 \%$ shading & &
\end{tabular}

${ }^{(1)}$ Means followed by the same small letter in the line and capital letter in the columns are not statistically different by Tukey's test at $5 \%$ probability.

The seeds harvested at green maturation stage have presented the worst physiological quality when compared to seeds harvested in the remaining stages. It was observed, however, that quality of these seeds was favored by shading, presenting better vigor when under $35 \%$ and $50 \%$ protection of solar radiation (Table 1). According to DaMatta (2004), reduction on productivity and higher "investment" of plants in their vegetative growth occur on shaded coffee plantations. As consequence of small number of beans per plant, these receive higher amounts of photosynthates, which allow for increases on their weight and can also influence chemical composition and vigor when produced under shading. Muschler, (2001) and Ricci et al. (2006) verified that shading has increased the size of coffee beans what was also reflected on their physical aspect, thus improving their sieve classification.

When percentage of normal seedling was assessed at the $30^{\text {th }}$ day after sowing, it was verified a behavior similar to those observed in radicle protrusion for seeds assessed at $15^{\text {th }}$ day after test beginning. The seeds harvested at cherry maturation stage have provided higher percentage of normal seedlings when assessed at $30^{\text {th }}$ day than the seeds harvested at the remaining maturation stages. It was also observed that, as in the radicle protrusion, it has not occurred effect of solar radiation levels on the physiological quality of seeds harvested at the cherry maturation stage. Oppositely, when seeds harvested at the initial stages of development (green and greenish-yellow) were assessed at the $30^{\text {th }}$ day, it was possible to observe that the shading has provided increase in the number of normal seedlings (Table 2). This fact, as observed by Ricci et al. (2006), may have occurred due to the lower production of beans per plant verified in the treatments carried out under shading, which can cause possible changes of photosynthates accumulation and consequently of weight and chemical composition of seeds.

Table 2. Percentage of normal seedlings grown from coffee seeds produced in three different levels of solar radiation and harvested in three different stages of maturation.

\begin{tabular}{cccr}
\hline \multirow{2}{*}{$\begin{array}{c}\text { Level of solar } \\
\text { radiation }\end{array}$} & Cherry & $\begin{array}{c}\text { Greenish- } \\
\text { yellow }\end{array}$ & Green \\
\cline { 2 - 4 } & $96 \mathrm{aA}^{(1)}$ & $41 \mathrm{bB}$ & $6 \mathrm{cC}$ \\
\hline Full sunlight & $97 \mathrm{aA}$ & $53 \mathrm{aB}$ & $29 \mathrm{aC}$ \\
$35 \%$ shading & $94 \mathrm{aA}$ & $49 \mathrm{aB}$ & $21 \mathrm{bC}$ \\
$50 \%$ shading & &
\end{tabular}

${ }^{(1)}$ Means followed by the same small letter in the line and capital letter in the columns are not statistically different by Tukey's test at $5 \%$ probability.

On evaluating abnormal seedling, it was verified that there was not significant effect of different solar radiation conditions and that this occurred only for seed maturation stages (Table 3). It was also observed that the cherry maturation stage has provided for seeds the capacity of producing lower number of abnormal coffee seedlings, hence confirming the higher quality of these seeds. Oppositely, the green and greenish-yellow maturation stages have provided for seeds the capacity of producing high percentages of abnormal seedlings what was probably a consequence of their physiological immaturity in these maturation stages. Concerning percentage of dead seeds at the end of the germination test, it was observed lower values for seeds harvested at the cherry maturation stage, followed by the greenish-yellow maturation stage (Table 4). In this assessment, seeds harvested within these stages were not influenced by the different solar radiation conditions, but the shading at the initial developmental stage (green) has promoted reduction on the number of dead seeds when compared with seeds produced under full sunlight (Table 4). 
Table 3. Percentage of abnormal seedlings grown from coffee seeds harvested in three different stages of maturation.

\begin{tabular}{cc}
\hline Stage of maturation & Abnormal seedling (\%) \\
\hline Cherry & $3 \mathrm{~b}^{(1)}$ \\
Greenish-yellow & $29 \mathrm{a}$ \\
Green & $28 \mathrm{a}$ \\
\hline
\end{tabular}

${ }^{(1)}$ Means followed by the same letter in the column are not statistically different by Tukey's test at $5 \%$ probability.

Table 4. Percentage of coffee seeds considered as dead seed during the germination test. The seeds were produced in three different levels of solar radiation and harvested in three different stages of maturation.

\begin{tabular}{cccc}
\hline \multirow{2}{*}{$\begin{array}{c}\text { Levels of solar } \\
\text { radiation }\end{array}$} & Cherry & $\begin{array}{c}\text { Greenish- } \\
\text { yellow }\end{array}$ & Green \\
\cline { 2 - 4 } & $2 \mathrm{aC}^{(1)}$ & $27 \mathrm{aB}$ & $66 \mathrm{aA}$ \\
\hline Full sunlight & $1 \mathrm{aC}$ & $22 \mathrm{aB}$ & $42 \mathrm{cA}$ \\
$35 \%$ shading & $3 \mathrm{aC}$ & $23 \mathrm{aB}$ & $54 \mathrm{bA}$ \\
$50 \%$ shading & &
\end{tabular}

${ }^{(1)}$ Means followed by the same small letter in the line and capital letter in the columns are not statistically different by Tukey's test at 5\% probability.

For the variable percentage of seedlings with fully opened cotyledonary leaves at 45 days after beginning of germination test, there was significant effect only for maturation stages; and the stage of cherry has allowed the best physiological performance for seeds, with the highest percentage of seedlings with opened cotyledonary leaves at 45 days (Table 5).

Table 5. Percentage of coffee seedlings with cotyledonary leaves fully opened at 45 days, grown from seeds produced in two stages of maturation.

\begin{tabular}{cc}
\hline Stage of maturation & $\begin{array}{c}\text { Seedling with open } \\
\text { cotyledonary leaves }(\%)\end{array}$ \\
\hline Cherry & $92 \mathrm{a}^{(1)}$ \\
Greenish-yellow & $37 \mathrm{~b}$ \\
\hline
\end{tabular}

${ }^{(1)}$ Means followed by the same letter in the column are not statistically different by Tukey's test at $5 \%$ probability.

Results herein achieved in assessing physiological quality of coffee seeds indicate that, under conditions in which this experiment was conducted, the seeds harvested at cherry maturation stage have presented the maximum physiological quality (Tables 1 to 5). These seeds were also assessed in relation to electrophoretic profile of isoenzymes and results obtained this manner indicate a beneficial effect of $35 \%$ shading on their quality (Figures 1 to 4 ). In the results obtained on assessing the effects of shading levels on physiological seed quality, a trend was also observed; although no significant differences for such effects have been detected. In a study on tolerance to desiccation of coffee seeds harvested at different maturation stages Brandão-Junior et al. (2002a) have also stated that seeds of this species have presented increase on levels of tolerance to desiccation with the advance of their development, indicating higher quality of these seeds at the final maturation stage (cherry).

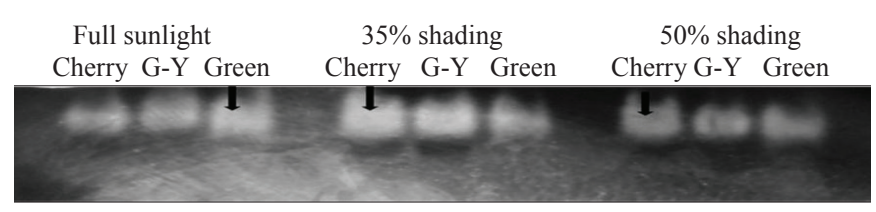

Figure 1. Isoenzymic profile of catalase found in seeds of Coffea arabica L. produced in three different levels of solar radiation and harvested in three different stages of maturation. Maturation stages: Cherry; Greenish-yellow (G-Y); and Green. Arrows indicate where higher isoenzymic activity occurred.

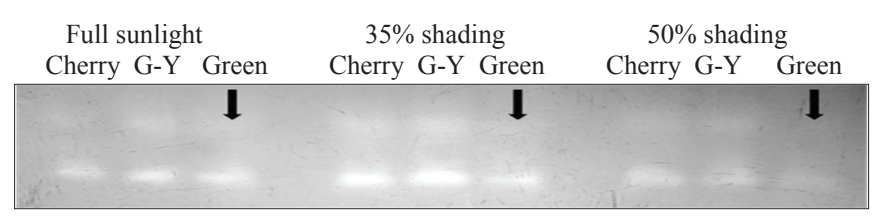

Figure 2. Isoenzymic profile of superoxide dismutase found in seeds of Coffea arabica L. produced in three different levels of solar radiation and harvested in three different stages of maturation. Maturation stages: Cherry; Greenish-yellow (G-Y); and Green. Arrows indicate where the lowest isoenzymic activity occurred.

The catalase enzyme constitutes an efficient deoxygenating mechanism, acting on removal of free radicals (McDonald, 1999). Within this study, variation on the activity of the catalase enzyme was detected in the seeds harvested in different developmental stages and produced under different levels of solar radiation. It was possible to observe higher activity of the catalase enzyme in the seeds produced at $35 \%$ shading than in the seeds produced in 
the remaining treatments of solar radiation. The activity of the catalase enzyme increases under shading and with the advance of the seed maturation stage; and in this study, for seeds harvested in the cherry maturation stages, this enzyme has presented higher activity. For seeds produced under full sunlight, however, this result was inverted, and the seed harvested at the green maturation stage were the ones presenting higher activity of catalase enzyme (Figure 1).

The superoxide dismutase enzyme is among the most important enzymes of defense system when linked to pathways of events needed to the full elimination of free radicals or reactive forms of oxygen (Alscher et al., 2002). The most intense activity of such enzyme was required during early or late phases of seeds maturation process; what is an indication of its defense action, with consequent reduction on free radicals formation. This might have occurred in function of deterioration process or physiological immaturity of seeds. Activity of the superoxide dismutase enzyme was lower in seeds produced under shading of $50 \%$ and higher in those produced under shading of $35 \%$. The lowest activity of such enzyme was observed in green seeds, in all levels of solar radiation during production process. These seeds, however, also presented the worst physiological performance, i.e., highest deterioration; so a higher activity of this antioxidant enzyme would be then the expected. However, after an extensive literature review and in a study on the events causing seed deterioration, Walters (1998) and McDonald (1999) have found many references on the enzymatic activity of superoxide dismutase enzyme either for reduction or increase of its activity with the seed deterioration process.

The esterase enzyme is also important in characterizing seed deterioration (Nakada et al., 2010). According to Walters (1998) and McDonald (1999) the lowest activity of such enzyme is related to events of seed deterioration. In this study, large differences in the electrophoresis analysis of the esterase isoenzymes among seeds produced under the different levels of solar radiation were not observed. The lowest activity was observed in seeds produced under shading of $50 \%$, independent of maturation stages. In relation to developmental stages of seeds, it was verified that seeds harvested in the green maturation stage have presented lower activity of this isoenzymes when compared with seeds harvested in the greenish-yellow or cherry maturation stages; what can be correlated with data on physiological quality (Figure 3). Brandão-Junior et al. (1999) have verified decrease on the number and intensity of electrophoretic esterase bands with the loss in viability of seeds, thus confirming results obtained in this study. Similar results were found by Brandão-Junior et al. (2002a) who also observed increase on intensity of electrophoretic bands with the increase of coffee seeds development.

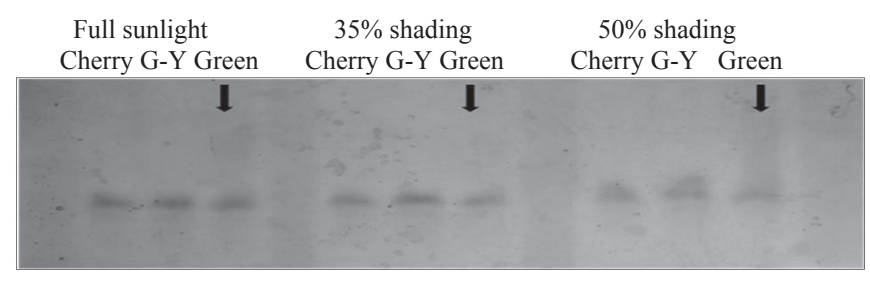

Figure 3. Isoenzymic profile of esterase found in seeds of Coffea arabica L. produced in three different levels of solar radiation and harvested in three different stages of maturation. Maturation stages: Cherry; Greenish-yellow (G-Y); and Green. Arrows indicate where the lowest isoenzymic activity occurred.

The activity of the peroxidase enzyme was the lowest in the seeds harvested at cherry maturation stage and produced under full sunlight (Figure 4). Brandão-Júnior et al. (2002a) also have verified lower activity of such enzyme in coffee seeds at the cherry maturation stage. Lower variation on the activity of this enzyme was verified when seeds were produced under shading of $50 \%$, independent of maturation stage (Figure 4). The presence of toxic products removal enzymes (scavengers enzymes) as the peroxidase, allows neutralizing the action of free radicals in the membrane degradation processes, due to the need of more intense activity of enzymes of the antioxidant complex (Marcos-Filho, 2005).

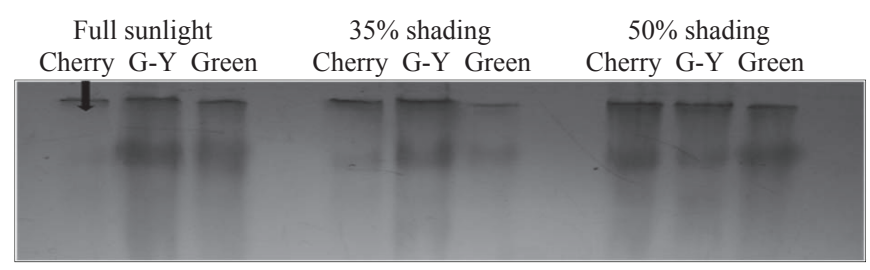

Figure 4. Isoenzymic profile of peroxidase found in seeds of Coffea arabica L. produced in three different levels of solar radiation and harvested in three different stages of maturation. Maturation stages: Cherry; Greenish-yellow (G-Y); and Green. Arrow indicates where the lowest isoenzymic activity occurred.

In a general way, coffee seeds harvested at the cherry maturation stage have presented higher physiological 
quality and were not influenced by the different levels of solar radiation; while the seeds harvested at the green maturation stage have presented the best results when produced under shadings of $35 \%$ and $50 \%$. The levels of solar radiation influenced deterioration degree of coffee seeds through changes in the activity of catalase, esterase, superoxide dismutase, and peroxidase enzymes.

\section{Conclusions}

Coffee seeds have increased physiological quality with the evolution of its development and at the beginning of its development have improved quality with the reduction of solar radiation.

\section{Acknowledgements}

Authors would like to thank to FAPEMIG and to "Instituto Nacional de Ciência e Tecnologia do CAFÉ" (INCT Café) for the financial support provided for the experimental work, and to CNPq by the grant of scholarships.

\section{References}

ALFENAS, A.C.; PERES, I.; BRUNE, W.; PASSADOR, G. C. Eletroforese de proteinas e isoenzimas de fungos e essências florestais. Viçosa: UFV, 1991. 242p.

ALSCHER, R.G.; ERTURK, N.; HEALTH, L.S. Role of superoxide dismutases (SODs) in controlling oxidative stress in plants. Journal of Experimental Botany, v.53, n.372, p.1331-1341, 2002. http://jxb. oxfordjournals.org/content/53/372/1331.full.pdf + html

BRANDÃO JUNIOR, D.S.; CARVALHO, M.L.M.; VIEIRA, M.G.G.C. Variações eletroforéticas de proteínas e isoenzimas relativas à deterioração de sementes de milho envelhecidas artificialmente. Revista Brasileira de Sementes, v.21, n.1, p.114-121, 1999.

BRANDÃO JUNIOR, D.S.; VIEIRA, M.G.G.C.; GUIMARÃES, R.M.; HILHORST, H.W.M. Tolerância à dessecação de sementes de cafeeiro (Coffea arabica L.). Revista Brasileira de Sementes, v.24, n.2, p.17-23, 2002a. http://www.scielo.br/scielo.php?script=sci_arttext\&pid=s0101$31222002000200004 \& \operatorname{lng}=$ pt\&nrm=iso\&tlng=pt

BRANDÃO JUNIOR, D.S.; VIEIRA, M.G.G.C.; HILHORST, H.W.M. Aquisição da tolerância à dessecação nos diferentes estádios de desenvolvimento de sementes de cafeeiro (Coffea arabica L.). Ciência e Agrotecnologia, v.26, n.4, p.673-681, 2002b. http://www.editora.ufla.br/ site/_adm/upload/revista/26-4-2002_02.pdf

BRASIL. Ministério da Agricultura, Pecuária e Abastecimento. Regras para análise de sementes. Ministério da Agricultura, Pecuária e Abastecimento.
Secretaria de Defesa Agropecuária. Brasília: MAPA/ACS, 2009. 395p. http://www.agricultura.gov.br/arq_editor/file/laborat\%c3\%b3rio/ sementes/regras\%20para\%20analise $\% 20 \mathrm{de} \% 20$ sementes.pdf

COPELAND, L.O.; McDONALD, M.B. Principles of seed science and technology. 4 ed. New York: Chapman and Hall, 2001. 467p.

DaMATTA, F.M. Ecophysiological constraints on the production of shaded and unshaded coffee: a review. Field Crops Research, v.86, n.2, p.99-114, 2004. http://www.sciencedirect.com/science/article/pii/s0378429003001977

FERREIRA, D.F. Sisvar - Sistema para análise de variância de dados balanceados: programa de análises estatísticas e planejamento de experimentos, versão 4. UFLA, 2003.

GOMES, I.A.C.; CASTRO, E.; SOARES, A.M.; ALVES, J.D.; ALVARENGA, M.I.N.; ALVES, E.; BARBOSA, J.P.R.A.; FRIES, D.D. Alterações morfofisiológicas em folhas de Coffea arabica L.cv. "Oeiras" sob influência do sombreamento por Acaia mangium Willd. Ciência Rural, v.38, n.1,p.109-115,2008. http://www.scielo.br/scielo.php?script=sci arttext\&pid=s0103-84782008000100018\&lng=pt\&nrm=iso\&tlng=pt

GUIMARÃES, R.M.; VIEIRA, M.G.G.C.; FRAGA, A.C.; VON PINHO, E.V.R.; FERRAZ, V.P. Tolerância à dessecação em sementes de cafeeiro (Coffea arabica L.). Ciência e Agrotecnologia, v.26, n.1, p.128-139, 2002. http://www.editora.ufla.br/site/_adm/upload/revista/26-1-2002_15.pdf

KANTEN, R.V.; VAAST, P. Transpiration of Arabica coffee and associated shade tree species in sub-optimal, low-altitude conditions of Costa Rica. Agroforestry Systems, v.67, n.2, p.187-202, 2006. https:// springerlink3.metapress.com/content/c4572632v371p415/resourcesecured/?target=fulltext.pdf\&sid=jnjnhinzb2yh4d552bnnjh55\&sh=www. springerlink.com

MACEDO, C.M.P.; LOPES, J.C. Qualidade fisiológica de semente de café arábica na presença de alumínio. Revista Brasileira de Sementes, v.30, n.1, p.66-73, 2008. http://www.scielo.br/scielo.php?script=sci arttext\&pid=s0101-31222008000100009\&lng=pt\&nrm=iso

MARCOS-FILHO, J. Fisiologia de sementes de plantas cultivadas. Piracicaba, SP: FEALQ, 2005. 495p.

McDONALD, M.B. Seed deterioration: physiology, repair and assessment. Seed Science and Technology, v.22, n.1/2, p.531-539, 1999. http://cat.inist. $\mathrm{fr} /$ ?amodele$=$ affichen $\&$ cpsidt $=1898410$

MENDES, A.N.G.; GUIMARÃES, R.J.; SOUZA, C.A.S. Classificação botânica, origem e distribuição geográfica. In: GUIMARÃES, R.J.; MENDES, A.N.G.; SOUZA, C.A.S. (Ed.). Cafeicultura. Lavras, MG: UFLA/FAEP. 2002. 39-98p.

MORAIS, H.; MEDRI, M.E.; MARUR, C.J.; CARAMORI, P. H.; RIBEIRO, A.M.A.; GOMES, J.C. Modifications on leaf anatomy of Coffea arabica caused by shade of Pigeonpea (Cajanus cajan). Brazilian Archives of Biology and Technology, v.47, n.6, p.863-871, 2004. http://www.scielo.br/scielo.php?script=sci_arttext\&pid=s1516$89132004000600005 \& \operatorname{lng}=\mathrm{pt} \& n \mathrm{~mm}=\mathrm{iso} \& \operatorname{lng}=\mathrm{en}$ 
MUSCHLER, R.G. Shade improves coffee quality in a sub-optimal coffee-zone of Costa Rica. Agroforestry Systems, v.51, n.2, p.131-139, 2001. http://www.springerlink.com/content/j1636h74x4430844/

NAKADA, P.G.; OLIVEIRA, J.A.; MELO, L.C.; SILVA, A.A.; SILVA, P.A.; PERINA, F.J. Desempenho durante o armazenamento de sementes de pepino submetidas a diferentes métodos de secagem. Revista Brasileira de Sementes, v.32, n.3, p.42-051, 2010. http://www.scielo.br/scielo.php?script=sci arttext\&pid $=$ s0101-31222010000300005\&lng $=$ en\&nrm $=$ iso

PEREIRA, C.E.; VON PINHO, E.V.R.; OLIVEIRA, D.F.; KIKUTI, A.L.P. Determinação de inibidores da germinação no espermoderma de sementes de café (Coffea arabica L.). Revista Brasileira de Sementes, v.24, n.1, p.306-311, 2002. http://www.scielo.br/scielo.php?script=sci arttext\&pid=S0101-31222002000100042\&lng=pt\&nrm=iso

RICCI, M.S.F.; COSTA, J.R.; PINTO, A.N.; SANTOS, V.L.S. Cultivo orgânico de cultivares de café a pleno sol e sombreado. Pesquisa Agropecuária Brasileira, v.41, n.4, p.569-575, 2006. http://www.scielo.br/scielo. php?script=sci_arttext\&pid=s0100-204x2006000400004\&lng=en\&nrm=iso

ROSA, S.D.V.F.; SANTOS, C.G.; PAIVA, R.; MELO, P.L.Q.; VEIGA, A.D.; VEIGA, A.D. Inibição do desenvolvimento in vitro de embriões de Coffea por cafeína exógena. Revista Brasileira de Sementes, v.28, n.3, p. $177-184, \quad 2006$. http://www.scielo.br/scielo.php?script=sci_ arttext\&pid $=$ s0101-31222006000300025\&lng $=$ pt\&nrm $=$ iso

ROSA, S.D.V.F.; CARVALHO, A.M.; McDONALD, M.B.; VON PINHO, E.R.V.; SILVA, A.P.; VEIGA, A.D. The effect of storage conditions on coffee seed and seedling quality. Seed Science and Technology, v.39, n.1, p.151-164, 2011. http://www.ingentaconnect.com/ content/ista/sst/2011/00000039/00000001/art00013
SOFIATTI, V.; ARAUJO, E.F.; ARAUJO, R.F.; REIS, M.S.; SILVA, L.V.B.D.; CARGNIN, A. Uso de hipoclorito de sódio para degradação do endocarpo de sementes de cafeeiro com diferentes graus de umidade. Revista Brasileira de Sementes, v.30, n.1, p.150-160, 2008. http://www.scielo.br/scielo.php?script=sci_arttext\&pid=s010131222008000100019\&lng=pt\&nrm=iso

VAAST, P.; BERTRAND, B.; PERRIOT, J.J.; GUYOT, B.; GÉNARD, M. Fruit thinning and shade improve bean characteristics and beverage quality of coffee (Coffea arabica L.) under optimal conditions. Journal of the Science of Food and Agriculture, v.86, n.2, p.197-204, 2006. http:// onlinelibrary.wiley.com/doi/10.1002/jsfa.2338/abstract

VEIGA, A.D.; GUIMARÃES. R.M.; ROSA, S.D.V. F.; VON PINHO, E.V.R.; SILVA, L.H.C.; VEIGA. A.D. Armazenabilidade de sementes de cafeeiro colhidas em diferentes estádios de maturação e submetidas a diferentes métodos de secagem. Revista Brasileira de Sementes, v.29, n. 1, p.83-91, 2007. http://www.scielo.br/scielo.php?script=sci arttext\&pid=S0101-31222007000100012\&lng=pt\&nrm=iso\&tlng=pt

WALTERS, C. Understanding the mechanisms and kinetics of seed aging. Seed Science Research, v.8, n.2, p.223-244, 1998. http://journals. cambridge.org/action/displayabstract? frompage $=$ online $\&$ aid $=1355988 \&$ fulltexttype $=$ ra\&fileid $=$ s096025850000413x 